Araştırma Makalesi

\title{
Eski Görüntüler, Yeni Görüngüler: Yeşilçam Filmlerinin Üslup Özellikleri İçin Uzak Okuma Denemesi
}

Serkan Şavk (Dr. Öğr. Üyesi)

İzmir Ekonomi Üniversitesi İletişim Fakültesi

savkserkan@hotmail.com

Başvuru Tarihi: 13.04.2020

Yayına Kabul Tarihi: 13.06.2020

Yayınlanma Tarihi: 24.07.2020

https://doi.org/10.17680/erciyesiletisim.719174

Öz

$\mathrm{Bu}$ araştırmada, Yeşilçam filmlerinin, YouTube üzerinden yığınsal biçimde uzaktan erişime açılması olarak tarif edebileceğimiz güncel gelişmeden hareket edilmektedir. $\mathrm{Bu}$ çalışmanın ilk amacı, Dijital İnsan Bilimleri ve film üslubunun istatistiksel analizi alanlarına ait yöntem ve araçları kullanarak Yeşilçam filmlerinin üslup özelliklerini uzak okuma yaklaşımıyla incelemektir. Çalışmanın ikinci amacı ise 1960'lı ve 70'li yıllar boyunca filmlerin biçim ve üslup özelliklerindeki dönüşümü sinema endüstrisinin tarihsel gelişimiyle ilișkilendirmektir. Böylece, kaynak yığınlarından karmaşık veri setleri üretilmesine dayanan analiz biçiminin Türk sinema tarihi açısından potansiyeli ortaya konulabilmektedir. Araştırmada, bir grup filmin metrik ölçümlemesi yapılmış ve ortaya çıkan veri seti, Yeşilçam'ın biçimsel dönüşümünü anlamak için kullanılmıştır. Makalenin ana araștırma sorusu, ortalama çekim uzunluğuna (OÇU) ve buna bağlı diğer verilere bakarak, 1960'tan 1979'a uzanan süreçte Yeşilçam filmlerinin üslup özelliklerinin açıklanabilir olduğunu göstermektir. Sonuç olarak, incelenen dönemde filmlerin üslup özelliklerinin zaman içerisinde hem dönüşüm hem de süreklilik gösterdiği ortaya konmuştur.

Anahtar Kelimeler: Sinema, Türk Sineması, Sinema Tarihi, Dijital İnsan Bilimleri, Film Üslubunun İstatistiksel Analizi. 


\title{
Old Images, New Phenomena: A Distant Reading Attempt for Stylistic Properties of Yeşilçam Films
}

\author{
Serkan Şavk (Asst. Prof. Dr.)
}

iD İmir University of Economics Faculty of Communication savkserkan@hotmail.com

Date Received: 13.04 .2020

Date Accepted: 13.06.2020

Date Published: 24.07.2020

https://doi.org/10.17680/erciyesiletisim.719174

\section{Abstract}

This research focuses on the recent release of the bulk of Yeşilçam films to remote access on YouTube. Our main goal is to study the stylistic properties of Yeșilçam films through distant reading approach by using methods and tools from Digital Humanities and statistical analysis of film style. The second goal is to relate the stylistic properties of the films to the historical development of the film industry. Thus, we demonstrate the potential of a method that is derived from the creation of complex data sets from visual resources. We did the metric measurement of a group of films and we used the data set for analyzing the formal transformation of Yeşilçam films. The main research question of this article is to prove that the stylistic properties of Yeşilçam films from 1960 until 1979 can be explained by analyzing average shot length (ASL) and other related data. We conclude that the stylistic properties of Yeșilçam films demonstrate both transformation and continuity through time.

Keywords: Cinema, Turkish Cinema, Film History, Digital Humanities, Statistical Analysis Of Film Style. 


\section{Giriş}

Yeşilçam filmleri, Türkiye'nin sinema tarihinde, popüler kültüründe ve toplumsal belleğinde büyük bir yere sahiptir. Muhtemelen bu makalenin okuyucuları da dâhil birçok günümüz izleyicisi, Yeşilçam filmleriyle aşinalık kuracaktır. Bu filmleri üreten endüstri ortadan kalkalı yaklaşık 30 yıl olmasına rağmen söz konusu aşinalığın devam ediyor olmasının temel kaynaklarından biri, Yeşilçam filmlerinin 1990'lardan itibaren televizyon kanallarında sıklıkla yayınlanmasıdır. Ancak, televizyon yoluyla günümüz izleyicisine ulaşan filmler, endüstrinin yaklaşık 40 yıllık ömrü boyunca gerçekleștirdiği üretimin çok sınırlı bir kısmını oluşturmaktadır. Diğer Yeşilçam yapımlarına yakın zamana kadar ya hiç ulaşılamıyordu ya da ancak çok düşük kaliteli kopyaları bulunabiliyordu. Bu durum, yapım ve dağıtım şirketlerinin ellerindeki Yeşilçam filmlerini son 5-6 yll içinde çevrimiçi video paylaşım platformu YouTube üzerinden paylaşmaya başlamasıyla radikal biçimde değişti.

$\mathrm{Bu}$ makalenin hareket noktasını, Yeşilçam filmlerinin dijital kopyalarının yığınsal biçimde uzaktan erişime açılması olarak tarif edebileceğimiz güncel gelișme olușturmaktadır. ${ }^{1}$ Makale, biri yaklaşım ve yönteme, diğeri sinema tarihine ilişkin iki amaç etrafında şekillenmiştir. Çalışmanın birinci amacı, Dijital İnsan Bilimleri ve film üslubunun istatistiksel analizi alanlarına ait bazı yöntem ve araçları kullanarak Yeşilçam filmlerinin üslup özelliklerini uzak okuma yaklaşımıyla incelemektir. Söz konusu yöntem ve araçlar, Türk sineması çalışmalarında çok sınırlı biçimde kullanıldığı için bu makale özgün bir yöntem denemesi niteliği tașımaktadır. 1960'lı ve 70'li yıllar boyunca filmlerin biçim ve üslup özelliklerindeki dönüşümün, sinema endüstrisinin iç dinamikleriyle ve tarihsel gelişimiyle ilişkilendirilmesi ise çalışmanın ikinci amacıdır. Böylece, kaynak yığınlarından karmaşık veri setleri üretilmesine dayanan analiz biçiminin Türk sinema tarihi açısından potansiyeli ortaya konulacaktır. Bu amaçlara ulaşmak için, yukarıda zikrettiğimiz dijital film yığınını esas alıp, 1960'lı ve 70'li yıllara ait bir grup filmin metrik ölçümlemesini yaptık. Böylece filmlerin biçimsel yapısına ilişkin kapsamlı bir veri seti oluşturduk. Bu veri setini uzak okuma yaklaşımıyla analiz ederek Yeşilçam'ın üslup özelliklerini anlamaya çalışacağız. Son olarak, filmlerin üslubunun endüstrinin üretim yapısıyla ilişkisine dair çıkarsamalarda bulunacağız. Bu çerçevede makalenin ana araştırma sorusu, ortalama çekim uzunluğuna (OÇU) ve buna bağlı diğer verilere bakarak, 1960'tan 1979'a uzanan süreçte Yeşilçam filmlerinin üslup özelliklerinin açıklanabilir olduğunu göstermektir. Makalenin Birinci Bölümü, konunun tarihsel arka planının daha iyi anlaşılmasına yönelik olarak Yeșilçam endüstrisinin tarihi, üretim yapısı ve içsel dinamikleri hakkında notlar içermektedir. İkinci Bölümde, çalışmanın amaç ve yöntemi üzerinde durulmuştur. Araştırmada kullanılan özgün yöntemin açık biçimde ortaya konulabilmesi için İstatistiksel Film Çalışmaları, Dijital İnsan Bilimleri ve Kitle Kaynak konuları ayrı başlıklar halinde ele alınmıştır. Çalışmanın örneklemi ve iş akışı da yine İkinci Bölümde açıklanmıştır. Üçüncü Bölüm, tamamen araştırma bulgularına ve bunların yorumlanmasına ayrılmıştır. Araştırmada kullandığımız yöntem ve yaklaşımın taşıdığı potansiyele ve mevcut yetersizliklerine ilişsin tartışma ise Sonuç ve Değerlendirme bölümünde ele alınmıştır.

\section{Yeşilçam Hakkında Notlar}

Bu bölümde, makalenin tarihsel arka planının ve ele alınan dönemin daha iyi anlaşlabilmesi için Yeşilçam hakkında bazı notlar paylaşılacaktır. Amacımız, Yeşilçam tarihi hakkındaki literatürün değerlendirmesini yapmak değildir. Yeşilçam tarihi ağırlıklı olarak Türk sineması araştırmalarının bir parçası olarak ele alınmıştır. Türkiye'de ulusal sinema uzun süre Yeşilçam'la özdeşleştiği için bu eğilim şaşırtıcı değildir. Ancak endüstrinin tarihinin ulusal sinema tarihinin içinden çalışılması beraberinde belli sınırları da getirmiştir. Endüstrinin 
ulusaşırı bağlantılarının literatürde uzun süre ihmal edilmesi bu sınırlardan birisidir. ${ }^{2}$ Bir başka sınır, ulusal sinema tarihyazımındaki teleolojik bakış açısının endüstrinin tarihine ilişkin çalışmalara da sirayet etmesidir. ${ }^{3}$ Söz konusu teleolojik bakışın kaynaklarından biri, Nijat Özön'ün (2010) ilk kez 1962'de yayınlanan ve literatürün kurucu metinlerinden biri olarak kabul edilen Türk Sineması Tarihi kitabıdır. Son yıllarda, sinema tarihyazımını ve Özöncü geleneği eleştiren birçok çalışma yayınlanmıştır (Yıldırım, 2016; Akser, 2014; Arslan, 2011; Okumuş, 2010; Özen, 2009; Kaya Mutlu, 2007). Tarihyazımına ilişkin tartıșmalarda, dönemlendirme sorunu üzerinde özellikle durulmakta ve yeni dönemlendirme önerileri Yeşilçam’ı merkeze alacak şekilde artmaktadır. Savaş Arslan (2011) Yeşilçam tarihini, Yeşilçam Öncesi (1940’ların sonuna kadar), Erken Yeşilçam (1950’ler), Yüksek Yeşilçam (1960'lar ve 1970’ler) ve Geç Yeşilçam (1980’ler) olmak üzere yaklaşık 40 ylllık bir süreci kapsayan beş dönemde incelemektedir. Arslan'ın bu önerisi, çok eleştirilen onar yllık dönemlendirme kalıbını tekrar etmekte, buna karşın Yeşilçam’ı belirleyen içsel ve dıșsal değişkenleri hesaba katmak bakımından tutarlı bir bakış açısı sunabilmektedir. Yeşilçam merkezli bir başka dönemlendirme önerisi Tunç Yıldırım'a (2016) aittir. Yıldırım, 1948’te yerli film gösteren sinema salonları lehine yapılan vergi indirimine kadar olan zamanı "Yeşilçam öncesi istikrarsız ve yetersiz film yapımı dönemi," 1948-1959 yılları arasını "Yeşilçam sinemasının oluşumu," 1960'ta toplumsal gerçekçi sinema hareketinin ortaya çıkışından 1971'de TRT'nin ulusal televizyon yayınına başlamasına kadar olan dönemi "Yeşilçam'ın altın çağı" ve 19721989 yılları arasını "Yeşilçam’ın ağır krizi” olarak dönemlendirmektedir (Yıldırım, 2016, ss. 24-26). Yıldırım ve Arslan'ın yaklaşımlarındaki ortak sorun, Yeşilçam tarihini "yükselme ve düşüş" paradigması çerçevesinde, doğrusal bir yaklaşımla ele almalarında yatmaktadır. Bunu karşın her iki dönemlendirme önerisi de hem Türk sineması hem de Yeşilçam tarihi bakımından tutarlı ve uygulanabilir yaklaşımlardır.

Arslan ve Yıldırım'ın yukarıda anılan dönemlendirmelerine göre Yeşilçam endüstrisi yaklaşık 40 yll faal olmuş ve bu süre boyunca Türkiye'de 5500'den fazla film üretilmiștir. ${ }^{4}$ Türkiye'de film yapımı 1940'ların sonundan itibaren tedricen artmış, yıllık ortalama film üretimi 1960'larda 200'e yaklaşmış, 1970'lerde bu sayının da üzerine çıkmıştır. Endüstrinin doruk noktasını oluşturan 1972 yılında toplam 301 film çekilmiştir. Yeșilçam, bu nicel üretkenliğe, endüstride uygulanan kimi tercih ve mekanizmalar sayesinde ulaşmıştır. Bunlardan birincisi, Yeșilçam'ın geliștirdiği finans modelidir. Nilgün Abisel'in (2005, s. 105) "ișletmeci egemenliği" olarak tanımladığı bu finans modelinde film üretimi, Anadolu'daki 6 işletme bölgesinden gelen salon işletmecilerinin verdiği avanslarla gerçekleștiriliyordu. Öyle ki, "ilkbahar aylarında İstanbul'a gelen işletmeciler, yapımcılarla görüşüp anlaşıyor, o yıl kaç adet ve ne türden film yapılacağının, bu filmlerde kimlerin rol alacağının saptanmasında en önemli rolü oynuyorlardı" (Abisel, 2005, s. 106).

Yeşilçam'ın film sayısını arttırmasını sağlayan bir diğer etmen, yapım süreci-film üslubu ilişkisi hakkındadır. Yeşilçam'ın yıllık film üretimi, 1960'ların ortalarından itibaren belirgin șekilde artmıştır. Nezih Erdoğan, endüstrideki bu büyümenin "kapasite arttırımı yerine üretimde hızlanmayı yeğleyen bir stratejiye dayandığını" (1998, s. 174) belirtmektedir. Bu strateji, yapım sürecindeki iki standartlaşmadan kaynaklanmaktadır. Bunlar, sesli çekim yerine dublajın kullanılması ve kamera yerleştirmelerinin sayısının azaltılmasıdır (Erdoğan, 1998, ss. 174-175). ${ }^{5}$ Kamera yerleştirilmelerinin mümkün olduğu kadar azaltılması özellikle diyalog sahnelerinde kendini gösteren bir tercih olmuştur. Erdoğan'ın $(1998$, s. 176) da ifade ettiği gibi, "çerçeve içinde, karakterlerin konumlanmaları birbirlerine göre değil kameraya göre tasarlanır; önemli anlarda yüzlerini kameraya dönerek konuşurlar ve eğer alan derinliği ikisini de kapsamıyorsa, netlik karakterlerin konuşma sırasına göre birinden diğerine kaydırılır." 
Yeşilçam endüstrisinin yüksek üretim kapasitesini borçlu olduğu bir diğer etmen, film hikâyelerinin/senaryoların yazılmasında takip edilen iktibas, yeniden çevirme, uyarlama ve intihal yöntemleridir. Filmlerin sınırlı bir kısmı orijinal senaryolar üzerine kuruluyken, çoğu film edebiyat uyarlamalarından, eski filmlerin yeniden çevrimlerinden ve özellikle Hollywood yapımlarından alınan hikâyelerden oluşuyordu. Bazı durumlarda, birden fazla filme ait olay örgüsü malzemesi tek bir film içinde bir araya getiriliyordu. ${ }^{6}$ Bazen de yabancı yapımlardan alınan içerik senaryoyla sınırlı kalmıyor, kimi filmlerden alınan görüntü ve sesler de değișen oranlarda kullanılabiliyordu. ${ }^{7}$

\section{Yöntem}

\subsection{Araştırmanın Amacı}

Bu araştırma, birbiriyle ilintili iki amaç etrafında şekillenmiştir. Çalışmanın birinci amacı, Dijital İnsan Bilimleri ve film üslubunun istatistiksel analizi alanlarına ait yaklaşım, yöntem ve araçları kullanarak Yeşilçam filmlerinin üslup özelliklerini incelemektir. $\mathrm{Bu}$ çerçevede, uzak okuma yaklaşımı, kitle kaynak, metrik ölçümleme ve ortalama çekim uzunluğunun hesaplanması yöntemleriyle Cinemetrics adlı ölçüm aracı kullanılmıştır. Burada bahsedilen yöntem, araç ve yaklaşımların bazıları, Türk sineması çalışmalarında çok sınırlı olarak kullanılmış olmakla birlikte (Bkz. Bölüm 2.2) bu çalışmadaki kapsam ve bileşimde ilk defa kullanılmaktadır. Dolayısıyla bu makale, özgün bir yöntem denemesinin örneğini oluşturmaktadır. Araştırmanın ikinci amacı, 1960-1979 yılları boyunca Yeşilçam filmlerinin biçim ve üslup özelliklerindeki dönüşümü sinema endüstrisinin iç dinamikleriyle ve tarihsel gelişimiyle ilişkilendirmektir. Veri setinin uzak okuması yapılırken, filmlerin yıllar içerisindeki genel üslup dönüşümüne ve bu üslup dönüşümü içinde diyaloglu ve diyalogsuz çekimlerin konumuna odaklanılmıştır. Bu çerçevede makalenin ana araştırma sorusu, OÇU'ya ve buna bağlı diğer verilere bakarak, 1960'tan 1979'a uzanan süreçte Yeşilçam filmlerinin üslup özelliklerinin açıklanabilir olduğunu göstermektir. Ana araştırma sorusunu cevaplayabilmek için şu yan araştırma soruları sorulmuştur: 1960'tan 1979'a uzanan süreçte, örneklemdeki filmlerin üslup özellikleri istatistiksel olarak nasıl bir dönüşüm göstermektedir? Aynı filmlere, diyaloglu ve diyalogsuz çekimlerin dağılımı açısından bakıldığında istatistiksel olarak nasıl bir farklılık görülmektedir? Söz konusu istatistiksel sonuçlar, filmlerin üslubuyla endüstrinin üretim yapısı arasındaki ilişki bakımından anlamlı sonuçlar sunmakta mıdır? Bu sorulara yanıt bulabilmek amacıyla, araştırmanın yaklaşım, yöntem, araç, iş akışı ve örneklemi hakkında detaylı bilgi aşağıdaki alt başlıklarda verilmiştir.

\section{2. İstatistiksel Film Çalışmaları ve Dijital İnsan Bilimleri}

Elinizdeki araştırma, kullanılan kuramsal çerçeve, yöntem ve araçlar bakımından Dijital İnsan Bilimlerinin ve film üslubunun istatistiksel olarak analiz edildiği araştırmaların kesişiminde yer almaktadır. Film üslubunun istatistiksel olarak analiz edilmesi, OÇU’nun belirlenmesi esasına dayanır. Bir filmdeki OÇU, filmin saniye düzeyindeki toplam süresinin o filmdeki çekim sayısına bölünmesiyle elde edilir. Elde edilen sonuç aynı yönetmene ya da kurgucuya ait filmlerin OÇU'sunun analiz edilmesi (artsüremli istatistik) ya da film tarihinin kesitleri arasında karşılaştırma yaparak kesme oranlarının anlaşılması için (eşzamanlı istatistik) kullanılabilir (Tsivian, 2009, s. 95). Bu sayede, filmlerin üslup ve biçim özelliklerinin analiz edilmesi hedeflenir. Çekim uzunlukları ve kesme oranları bir filmin üslup ve biçim özelliklerinden sadece bir kısmını oluşturur. Buna rağmen, filmin üslubu hakkında bize çok şey anlatırlar çünkü sinema tarihi boyunca yönetmen ve kurgucuların sık sık üzerinde durduğu gibi kesme eylemi, filmdeki anlam inşasının en temel araçlarından biridir. 
Literatürde genellikle Avusturalyalı sinema tarihçisi Barry Salt'ın OÇU hesaplamasına dayalı analiz çabasını başlatan kişi olduğu kabul edilir. David Bordwell, Salt'ın, "betimleyici/ analitik bir araç olarak ortalama çekim uzunlukları değerine" ilk olarak 1974 tarihli bir makalesinde odaklandığını yazar (Bordwell, 2006; Salt, 1974). Ancak Salt'ın kendisi, Film Style and Technology kitabında (2009), üslup analizine ilişkin yöntemini geliştirirken daha önce edebiyat ve müzik alanlarında ortaya çıkan istatistiksel analiz örneklerinden ilham aldığını belirtir. Ayrıca kendisinden çok daha önce filmlerin çekim uzunluklarını ve kesme oranlarını analiz eden araştırmacılar olduğunu ekleyerek Herbert Birett ve Elias Boudinot Stockton'ın çalışmalarına işaret eder (Salt, 2009, s. 155). Kristin Thompson da, 1926 yllında Georg Otto Stint'in, Alman ve Amerikan filmlerindeki bağıl çekim uzunluklarına odaklandığı bir çalışma yaptığını belirtir (Stindt, 1926; Thompson, 2005, s. 117). ${ }^{8}$

Görüldüğü gibi filmlerin üslup özelliklerinin çekim uzunluklarına odaklanan istatistiksel yöntemlerle analiz edilmesi görece eski bir uğraştır. Ancak bu uğraşa belli bir yoğunluk kazandıran Barry Salt olmuştur. Salt, uzun araştırma kariyeri boyunca istatistiksel yöntemleri kullandığı birçok çalışma yapmış, bunların önemli bir kısmını da Film Style and Technology (1983) kitabında bir araya getirmiştir. ${ }^{9}$ Salt'ın, OÇU'nun yanı sıra çekim ölçeği ve kamera hareketi verilerine odaklandığı çalışmaları, dönemsel ve/veya endüstriler arası karşılaştırmalar içermesi bakımından önem taşımaktadır. Salt'ın açtığı yolda ilerleyen birçok araştırmacı, filmlerin üslup özelliklerini farklı istatistiksel yöntemlerle analiz ettikleri çalışmalar yapmışlardır. Örneğin Brett Adams, Chitra Dorai ve Svetha Venkatesh (2002), dijital videoların arşiv ve indekslenmesindeki semantik yetersizliklerin aşılmasına yönelik olarak film gramerine yönelmişlerdir. Bu araştırmacılar, bir filmde anlam inşasının temel kurallarını oluşturan film gramerinden hareketle filmin dizemini analiz etmektedirler. Nick Redfern (2012a, 2012b, t.y.), belli bir yönetmenin filmlerindeki ya da bir film kümesindeki çekim uzunluğu dağılımlarını incelediği araştırmalar yapmış, bunun yanı sıra istatistiksel yöntemlerin filmlerin üslup analizinde nasıl kullanılacağına ilişkin teorik makaleler kaleme almıştır (Redfern, 2013, 2014, 2015).

Chicago Üniversitesi'nde Yuri Tsivian'ın öncülüğünde yürütülen Cinemetrics projesi, istatistiksel/nicel film çalışmalarının gelişimi açısından büyük önem taşımaktadır. Cinemetrics, "filmler hakkında bilimsel veri toplamak, saklamak ve işlemek için tasarlanmış açık erişimli bir etkileşimli web sitesidir" (Tsivian, 2009, s. 93). Projenin halihazırdaki odak noktasını filmlerdeki kesme oranlarının anlaşılması oluşturmaktadır ve bu çerçevede herkesin kullanımına açık bir ölçümleme aracı geliştirilmiştir. Frame Accurate Cinemetrics Tool (FACT) ve Classic Cinemetrics Tool (CCT) olmak üzere iki ayrı versiyonu bulunan bu araçla yapılan ölçümler, yine aynı proje kapsamında geliştirilen veri tabanına yüklenmektedir. Veri tabanı, her film için bir sayfa yaratmakta, bu sayfa üzerinden filmin ham verisi, bu veriye ilişkin istatistiksel sonuçlar ve çekim değişimleri grafiği görüntülenmektedir. Cinemetrics projesi, ilgili literatüre büyük bir ivme kazandırmış, bu proje etrafında toplanan bir grup araştırmacı, istatistiksel yöntemleri farklı bakış açılarıyla kullandıkları araştırmalar gerçekleştirmiştir. ${ }^{10} \mathrm{Bu}$ araştırmacılardan biri olan Mike Baxter (2014), Cinemetrics projesi çerçevesinde biriktirdiği yöntemsel malzemeyi açık erişimli bir monografi halinde paylaşmıştır.

Türk sineması çalıșmalarında, film üslubunun istatistiksel olarak analiz edildiği yöntemler çok sınırlı olarak kullanılmıştır. Bu çalışmalardan biri Aydın Çam’ın (2016) Derviş Zaim sinemasına odaklandığı doktora tezidir. Çam, kurgu-söküm adını verdiği teknikte, bir kurgu yazılımı aracılığıyla Derviş Zaim filmlerinde mekân değişimlerini 
tespit ederek filmi çekimlerine ayırmıştır. Ürettiği nicel veri setini daha sonra Zaim'in filmlerinde mekânın estetik ve anlatısal önemini açıklamak için kullanmıştır (Çam, 2016, ss. 33-36). Çekim uzunluğunun ölçümlenmesine dayanmamakla birlikte, üslup analizinde istatistiksel yöntemlerin kullanıldığı bir diğer çalışma Çağrı İnceoğlu'nun (İnceoğlu, 2015) optik kaydırma hakkındaki makalesidir. Yeşilçam filmlerinde optik kaydırma kullanılan çekimlerin sayısını karşılaştıran İnceoğlu, 1964'ten 1971'e uzanan sekiz yıllık dönemde, optik kaydırma hareketinin dramatik biçimde arttığını ortaya koyarak bu artışın filmlerin estetik yapısındaki etkisini analiz etmiştir.

Film üslubunun analizinde kullanılan istatistiksel yöntemler bazı çalışmalarda başka yöntem ve yaklaşımlarla bir arada kullanılmaktadır. Örneğin, Lev Manovich (2013) tarafından yürütülen ve Dziga Vertov'un iki filminin görsel analizine odaklanan Visualizing Vertov projesinde, gelişmiş veri görselleştirme yöntemleri çekim uzunluklarına ilişkin verilerle bir arada ele alınmıştır. Oluşturulan görselleștirmeler, film karelerinin ortalama gri skalası, kontrast, şekil sayısı, kenar sayısı ya da farklı renk ve dokuların nispi oranı gibi değerlerden oluşmaktadır. "Filmlerin, görselleştirmeyle birleştirilen sayısal analizinin, sinemanın ve diğer zaman-tabanlı medya türlerinin bazı yönlerini 'tersine mühendislik'e tabi tutmamıza imkân verdiğini" (Manovich, 2013, s. 4) belirten araștırmacı, bu bağlamda Dziga Vertov'un sinema-göz kavramından yararlanmaktadır. Vertov'a göre sinemagöz, görünmez olanın görünür kılınmasına olanak sağlar. Tıpkl, sinema-göz gibi veri görselleştirmesi de görünmez olanı görünür kılarak verinin içindeki kalıpları ortaya çıkarmaktadır (Manovich, 2013, s. 4).

\subsection{Uzak Okuma Yaklaşımı}

Buraya kadar verdiğimiz örneklerin gösterdiği üzere, filmlerin dijital yöntem ve araçlarla incelenmesinde iki ana yaklaşım bulunmaktadır. Birinci yaklaşımda, tek bir filmin ya da küçük bir film grubunun çok detaylı olarak incelenerek bir çeşit sondaja tabi tutulması amaçlanırken ikinci yaklaşımda daha geniş bir film grubunun çeşitli düzlemlerde karşılaştırmalı olarak incelenmesi hedeflenmektedir. Söz konusu iki yaklaşım aslında yakın okuma ve uzak okuma yaklaşımlarıyla ve bu ikisi arasındaki ayrım ve/veya çatışmayla örtüşmektedir. Yakın ve uzak okuma yaklaşımlarına ilișkin tartışmalar, Dijital İnsan Bilimlerine ve büyük veri (İng. big data) çalışmalarına odaklanan çevreleri yoğun şekilde meşgul etmektedir.

Edebiyat eleştirisi alanından gelen yakın okuma, metinlerin semantik ve üslup özelliklerine odaklanarak bunlar arasındaki karmaşık tutarlık ve amacı ortaya koymaya çalışan bir yaklaşımdır. Edebî metinlerin bu şekilde "yakından" okunması aslında eleştirmenlerin ve okuyucuların yüzyıllardır yaptığı bir şeydir ancak kavramsal olarak yakın okuma, daha ziyade Yeni Eleștiri Kuramıyla ilișkilendirilmiştir (Gardner, 2012, s. 268). Yeni Eleștiri, tıpkı Şikago Okulu gibi, edebiyat eleştirisinde 20. yüzyılın başında görülen biçimci eğilimin yoğunlaştığl kuramsal yönelimlerden birisidir. Bu kuram, "edebiyatın estetik niteliklerine tarihsel, psikolojik ve ahlakî değerlendirmeler karşısında öncelik" (Habib, 2005, s. 621) vermekteydi. Bununla beraber, kendinden önceki biçimci analizcilerden de ayrılıyordu. Habib'e (2005, s. 603) göre "biçimcilerin analizi çok daha kuramsaldı, edebiyatın genel doğasını, edebî araçları ve yanı sıra edebî tekniklerin tarihsel evrimini anlamaya yöneliyordu. Yeni Eleștiriciler teoriden ziyade tekil metinlerin yakın okuma pratiğiyle ilgileniyorlardı." Görüldüğü üzere yakın okuma yaklaşımında, tekil bir edebî metnin biçimsel özellikleri, metnin üretildiği çeşitli bağlamlardan bağımsız olarak, metnin içsel nitelikleri okunarak analiz edilmektedir. Yakın okuma çoğunlukla, dijital öncesi döneme ait bir yaklaşım olarak kodlanır ancak bu kısmen yanıltıcıdır 
çünkü bir metnin yakın okumasını yapmaya yarayan dijital araçlar bulunduğu gibi yakın okuma tercihi Dijital İnsan Bilimleri çevrelerinde de devam etmektedir (konvansiyonel ve dijital yakın okuma pratiklerinin karşılaştırması için bkz. Jänicke, Franzini, Cheema ve Scheuermann, 2015, s. 2).

Franco Moretti tarafından geliştirilen uzak okuma da tıpkı yakın okuma gibi edebiyat eleştirisi alanından gelen bir yaklaşımdır. Yazar bu kavramı ilk kez 2000 yılında ortaya atmış (Moretti, 2000), daha sonra 2005 tarihli kısa kitabında konuyu detaylı olarak ele almıştır. ${ }^{11}$ Moretti'nin uzak okuma yaklaşımı, geleneksel olarak edebiyat araştırmalarının sınırlı oranda etkileşime girdiği üç disiplini işin içine katmaktadır: Nicel tarihin grafikleri, coğrafyanın haritaları ve evrimsel teorinin ağaçları. Uzak okuma, grafik, harita ve ağaçların sunduğu şekil ve ilişkiler sayesinde, daha çok sayıda elemanı daha etraflı şekilde analiz etmeye imkân sağlamaktadır. Bu yaklaşımın arka planında kendi Marksist formasyonunun yattığını söyleyen Moretti (2007, ss. 1-2), çağdaş edebiyat eleştirisi Fransız ve Alman metafiziğine yönelirken doğa bilimleri ve sosyal bilimlerden öğrenecek hala çok şey olduğunu vurgulamaktadır. Uzak okumanın yapı taşlarını oluşturan grafik, harita ve ağaçlar, somut analizler yerine soyutlamalardan ve modellerden oluşmaktadır. Ancak, bu soyut modeller görselleştirmeden güç almakta, bir başka ifadeyle, daha önce görmediğimiz bağlantıları görünür kılmamızı sağlamaktadır.

Yaklaşımını detaylandırmak için İngiliz edebiyat tarihinden örnek veren Moretti, 19. yüzyılı çalışırken yaklaşık 200 romandan oluşan bir kanona bakıldığını, bunun kapsayıcı bir rakam gibi görünse de o dönemde yayınlanan romanların yüzde birinden bile daha az olduğunu, toplam rakamın tam olarak bilinmese de 20-30 bin civarında tahmin edildiğini yazmaktadır. Bu boyutta bir roman kütlesini yakın okuma yoluyla tek tek incelemek yllar sürecek bir uğraş olacaktır. Dahası mesele bir zaman değil yöntem meselesidir. Bu kadar büyük bir sahayı anlamak için tekil vakaları birbirine iliştirmek yerine bunlara bir bütün olarak bakmak ve aralarındaki kolektif sistemi anlamak gerekmektedir (Moretti, 2007, s. 4). Moretti, büyük bir metin yığınını bütünlüklü olarak anlamamızı sağlayacak nitel verinin yorumdan bağımsız olduğu için kullanışlı olduğu kanaatindedir. Ancak bu veriler aynı zamanda nitel alanın sınırlarını aşan bir yorumlamayı gerektirir (Moretti, 2007, s. 30). Bu da bizi, yakın okumayla uzak okuma arasındaki değişmeyen ortak noktaya yani araştırmacının yorumlayıcı olarak dahline götürmektedir.

Moretti'nin uzak okuma yaklaşımının Dijital İnsan Bilimleriyle ve büyük veri çalıșmalarıyla uğraşan çevrelerde büyük bir popülerlik kazanması tesadüf değildir. Tarihsel süreç içinde devasa metin yığınlarının üretildiği tarih, edebiyat ve coğrafya gibi alanlara ait metinsel kaynaklar 1990'lardan itibaren yoğun șekilde dijitalleștirilmiștir. ${ }^{12}$ Önceleri CD-ROM gibi formatlarda ya da çevrimdışı veri tabanlarında toplanan dijitalleştirilmiş metinler 2000 'lerle birlikte çevrimiçi mecralara taşınmıştır. 2004'te Google Books projesinin başlaması, 1996'da henüz yeni bir mecra olan İnterneti arşivlemek için kurulan Internet Archive'ın 2005 yılında kitap dijitalleștirme programı başlatması ("Internet Archive: About IA", t.y.) ya da aynı yıllarda Gutenberg Projesindeki dijital kitap sayısının radikal şekilde artması (Lebert, 2008) gibi süreçler sonunda araştırmacılar on binlerce dijital metne ulaşabilir hale gelmiştir. Bu gelişme, Moretti'nin çizdiği panoramanın somut örneğini oluşturmaktadır. Bir yandan birkaç on yll önce düşünülemeyecek miktarda metin erişime açlırken diğer yandan hiçbir araştırmacının hatta projenin ömrü bütün bu metinlerin tek tek analiz edilmesine el vermeyecektir. Bu koşullar altında birçok tarihçi, uzak okuma yaklaşımına yönelmiştir. 


\subsection{Kitle Kaynak Yöntemi}

Yukarıda ana hatlarını çizdiğimiz uzak okuma yaklaşımı, kaynak materyallerden veri setleri çıkarılmasını gerektirmektedir. Bazı kaynak türlerinde (örneğin dijital formattaki metinsel kaynaklar) söz konusu veri çıkarma süreci görece otomatikleştirilebilmektedir. Ancak el yazmaları ya da görsel kaynaklar gibi malzemelerde veri çıkarma işlemi emek yoğun bir süreci gerektirmektedir. Bu ihtiyacı karşılamak için Dijital İnsan Bilimlerinde yaygın olarak kitle kaynak yöntemine başvurulmaktadır. Kitle kaynak kavramı ilk olarak 2006 yılında Jeff Howe (2016) tarafından ünlü inovasyon ve teknoloji dergisi Wired'da kullanılmış, takip eden yıllarda dijital platformları kullanan ticari, yaratıcı ya da akademik projelerin başlıca yöntemlerinden biri haline gelmiştir. Daren Brabham, kitle kaynağı "çevrimiçi toplulukların kolektif zekâsını belirli örgütsel amaçlara yardım etmek için kaldıraç olarak kullanan çevrimiçi, yayılmış bir sorun çözme ve üretim modeli" (2013, s. xix) olarak tanımlamaktadır. Kavrama dijital tarih perspektifinden bakan Despoina Valatsou ise kitle kaynağı "bir projenin gerçekleștirilmesine katkıda bulunacak insan kitlesini cezbetmek için açık çağrının kullanılması süreci” (2014, s. 30) olarak tarif etmektedir. Kitle kaynakta, yaratıcı süreç örgütle kamu arasındaki bir alanda gerçekleşir. Bu süreçte üretim hiyerarşik olarak aşağıdan yukarıya doğru ve açık biçimde yapılırken yönetim yukarıdan aşağıya doğru gerçekleșir (Brabham, 2013, s. xxi). Bir başka ifadeyle kitle kaynak, bir örgütte hiyerarşinin yukarısı tarafından tanımlanan bir sorunun açık çağrıya icabet eden geniş bir gönüllü katılımcı grubu tarafından çözümlenmesi anlamına gelir. Çevrimiçi ortamlarda imece usulüyle veri veya içerik üretilen birçok platform için (örneğin Wikipedia) kitle kaynak tabiri kullanılsa da aslında bu genel kullanım yöntemin içeriğini tam olarak açıklamamaktadır. Brabham'a göre (2013, s. 4), geniş bir katılımcı/kullanıcı grubu tarafından imece usulüyle yapılan bir üretimin kitle kaynak olup olmadığını anlamak için kontrolün örgütle topluluk arasında konumlanması gerekmektedir. Wikipedia örneğinde, kitle aslında kendisini yönetmekte ve üretim sürecinde örgütün neredeyse hiçbir dahli bulunmamaktadır. Bunun tam tersi durumlarda, yani ağırlığın örgütsel hiyerarşinin üst basamaklarına kayıp topluluktan uzaklaştığı durumlardaysa kitle, örgütün amaçlarına ulaşmasını sağlayan bir piyona dönüşmektedir.

Dönemsel olarak bakıldığında, tarihsel metinlerin dijital olarak erişime açılmasıyla kitle kaynak yönteminin yaygınlaşması arasında paralellik olduğu görülür. Kitle kaynak, devasa metin yığınlarının işlenmesini ya da bu metinlerin satır aralarında yer alan bilgilerin doğrulanmasını başka yöntemlerle ulaşılamayacak oranda hızlandırmıştır. Eğer uzak okuma, büyük kaynak yığınlarını analiz etmek için anlamlı bir yaklaşımsa kitle kaynak da bu yaklaşımın hayata geçirilmesine vesile olan bir yöntemdir.

\section{5. Örneklem ve İş Akışı}

Bu araştırmada, Savaş Arslan'ın (2011), Yüksek Yeşilçam olarak belirlediği 20 yıllık dönemden (1960-1979) bir grup film metrik olarak ölçümlenip analiz edilmiştir. Filmlerin ölçümlenmesinde, Cinemetrics projesi kapsamında geliştirilen FACT ve CCT uygulamaları kullanılmıștır. Filmlerin belirlenmesinde, YouTube kanallarındaki filmler esas alınmıştır. Çalışmaya başladığımız 2017 Mart ayı itibariyle, bu platform üzerinden paylaşılan Yeşilçam filmlerinin sayısı, bugünkü duruma göre çok daha azdı. Bu sınırlı çerçeve içinde, filmleri en çok paylaşılan yönetmenler arasından Osman Seden (1924-1998), Orhan Elmas (1927-2002) ve Orhan Aksoy (1930-2008) isimlerine odaklanmaya karar verdik. Bu üç yönetmeni, kariyerlerindeki paralellikler, dönemsel örtüşme ve endüstri içinde temsil ettikleri konum bakımından seçtik. Yönetmenlik kariyerlerine 1950'lerin ortasından 1960'ların ortasına uzanan dönemde başlayan bu üç sinemacı, Yüksek 
Yeşilçam Dönemi'nin en üretken isimleri arasında yer almaktadırlar. Yönettikleri filmler arasında dram, melodram ve komedi türündekiler ağırlıklı yer tutarken, macera, polisiye, fantastik ve bilimkurgu türlerinde çok daha az sayıda film yönetmişlerdir. Bu bakımdan her üç isim de Yeşilçam'ın anaakım yönetmenleri arasında yer almaktadırlar. Nitekim örneklemdeki filmlerin çoğunluğunu dram, melodram ve komediler oluşturmaktadır. ${ }^{13}$ $\mathrm{Bu}$ üç yönetmenin filmlerine ek olarak, 1960'lı ve 70'li yıllardan dikkat çeken başka yönetmenlere ait popüler filmler de analiz listesine eklenmiştir.

Bir filmin ölçümlenmesi, ölçümü yapan kişinin programı kullanma hızına bağlı olarak filmin toplam süresinin 2-2,5 katı kadar sürmektedir. Dolayısıyla bir filmin ölçümlenmesi son derece emek yoğun ve uzun zaman alan bir süreçtir. Hedeflenen örnekleme ulaşmak için bir ya da birkaç kişinin ölçüm yapması yeterli olmayacağından filmlerin ölçümlenmesini organize etmek için kitle kaynak yöntemi kullanılmıştır. Bu çalışmadaki katılımcı grubunu, 2016-2017 öğrenim yılı bahar dönemiyle 2017-2018 öğrenim yılı güz ve bahar dönemlerinde, İzmir Ekonomi Üniversitesi'nde verilen Türk Sineması dersini alan öğrenciler oluşturmaktadır. Her öğrenciye örneklemdeki filmlerden biri verilmiş ve öğrencilerden bu filmi FACT uygulamasını kullanarak ölçümleyip bu sonuçları veri tabanına yüklemesi istenmiştir. Öğrenciler bu şekilde yaklaşık 150 ölçümleme yapmıştır. Hatalı ölçümler ayıklandıktan sonra toplam 100 filme ait ölçüm sonuçları analize dâhil edilmiştir. ${ }^{14}$ Sonuç olarak ortaya Tablo 1'de görülen örneklem profili çıkmıştır.

Tablo 1: Örneklemdeki Yönetmenlerin Toplam ve Ölçümlenen Film Sayıları

\begin{tabular}{|l|c|c|c|c|c|}
\hline & \multicolumn{2}{|c|}{ Film sayısı } & \multicolumn{3}{c|}{ Örneklemdeki ölçümlenen film sayısı } \\
\hline Yönetmen & $\mathbf{1 9 5 0 - 1 9 8 9}$ & $\mathbf{1 9 6 0 - 1 9 7 9}$ & Basit & Gelişmiş & $\mathbf{1 9 6 0 - 1 9 7 9}$ \\
\hline Osman Seden & 140 & 96 & 3 & 30 & $\% 34,37$ \\
\hline Orhan Elmas & 113 & 65 & 6 & 17 & $\% 35,38$ \\
\hline Orhan Aksoy & 84 & 68 & 1 & 36 & $\% 54,41$ \\
\hline Ertem Eğilmez & 44 & 39 & 0 & 4 & $\% 10,25$ \\
\hline Atıf Yılmaz & 108 & 74 & 0 & 2 & $\% 2,7$ \\
\hline Temel Gürsu & 84 & 39 & 0 & 1 & $\% 2,56$ \\
\hline TOPLAM & & & 100 & 90 & \\
\hline
\end{tabular}

FACT uygulaması, her çekimin son karesinin kullanıcı tarafından işaretlenmesi ilkesine dayanmaktadır. $\mathrm{Bu}$ sayede, çekimlerin başlangıç ve bitiş karelerinin zaman kodlarından oluşan bir veri yaratılmaktadır. Uygulama ayrıca, her çekime belli bir nitelik atanmasına olanak sağlamaktadır. Uygulamanın standart versiyonu, çekim ölçeklerinden oluşan yedi bileșenli bir cetvelle hazır olarak gelmektedir.

Katılımcılardan filmleri aşağıdaki kurallara göre ölçümlemeleri istenmiştir. Açllış ve kapanış jenerikleri filmin ölçümlenen kısmının dışında tutulacak ve ölçümleme, açılış jeneriğindeki son yazının göründüğü çekimi takip eden ilk çekimde başlatılacaktır. Jenerik kısmı, iki sebeple ölçümün dışında tutulmuştur. Birinci sebep, filmlerin jenerik teknikleri arasında bütünlük bulunmaması, bazı jenerik sekansları çekimlerden oluşurken bazılarının canlandırma ya da salt tipografik unsurlar içermesidir. İkinci sebep, film kopyalarının başlangıç ve bitiş kısımları fiziksel olarak çok fazla yıprandığı için bazı filmlerin jeneriklerinin daha sonra yeniden üretilmesidir. Dolayısıyla bu jeneriklerin, filmlerin orijinal kopyasına ait olduğunu kanıtlamak mümkün değildir. Çekimler arasında kesme yerine zincirleme etkisinin kullanıldığı durumlarda, birinci çekimin görünür olmaya devam ettiği son kare o çekimin son karesi olarak kabul edilecektir. Çekim uzunluklarının belirlenmesine dayanan metrik ölçümleme sisteminin doğal sonucu olan bu durum, bindirme etkisinin görmezden gelindiği anlamını 
taşımamaktadır. Bir filmin metrik ölçümlemesi yapılırken sadece çekimler belirlenmekte ve çekimlerin arasında başka bir görüntü kategorisi, boşluk, kararma, vb. tanımlanmamaktadır. Kaldı ki Yeşilçam, 1960'tan itibaren zincirleme etkisinden büyük oranda vazgeçmiştir (Yıdırım, 2018, s. 620). YouTube'daki videonun, filmin başa dönmesi, filmin devamında uzun süre siyah ekran ya da başka görüntüler olması gibi nedenlerden ötürü film süresini aştığı durumlarda, tarafımızdan katılımcıya zaman kodları verilen aralık ölçümlenmiştir.

Örneklemdeki 100 ölçümün 90 tanesi gelişmiş, diğer 10 tanesi basit ölçümlemedir. Yukarıda belirtildiği üzere Cinemetrics uygulamaları, ölçümlenen çekime belli bir nitelik tanımlanmasına olanak vermektedir ve bu işlevin kullanıldığ ölçümler veri tabanında gelişmiş ölçüm olarak kaydedilmektedir. Katılımcılar ölçümleme sırasında, her bir çekimde sözel unsur olup olmadığına bakarak, her türlü insan sesinin yer aldığı çekimleri D (diyaloglu) insan sesinin yer almadığı çekimleri ise ND (diyalogsuz, İng. no dialogue) şeklinde işaretlemiştir. Veri tabanında gelişmiş olarak görülmeyen 10 ölçümlemede ise ya katılımcı N-ND kıstaslarını kullanmayı ihmal etmiş ya da ölçümleme gelişmiş olarak yapıldığı halde veri tabanına yüklenirken yanlışlıkla basit ölçümleme seçeneği işaretlenmiştir. Diyaloglu çekimlerin dağılımına ilişkin bulgu ve yorumlarda sadece gelişmiş ölçümlerden yararlanılırken, diğer tüm analizlerde gelişmiş ve basit ölçümlere ilişkin veri seti bir arada kullanılmıştır.

Örnekleme dâhil edilen 100 filmin, 93 tanesi FACT, 7 tanesi de CCT uygulamasıyla ölçümlenmiştir. 2017-2018 Bahar döneminde, ölçümleme sırasında FACT uygulamasıyla ilgili birçok uyumluluk sorunu yaşanmış, alternatif olarak CCT uygulaması kullanılmıştır. FACT ve CCT araçlarının herhangi biriyle yapılan tüm basit ve gelişmiş ölçümler, veri tabanına yüklendikten sonra her bir film için, ortalama çekim uzunluğu (OÇU), ortanca (medyan) çekim uzunluğu (MÇU), ortanca çekim uzunluğunun ortalama çekim uzunluğuna oranı (MÇU/OÇU), filmin ölçümlenen toplam süresi, filmdeki toplam çekim sayısı (TÇS), en uzun çekim (EUÇ), en kısa çekim (EKÇ), en uzun ve en kısa çekimler arasındaki fark, standart sapma (SS) ve varyasyon katsayısı olmak üzere on istatistiksel değer elde edilmektedir.

Örneklemdeki 100 filme ilişkin istatistiksel veriler Cinemetrics veri tabanından kopyalanarak bu filmlere ilişkin künye bilgileriyle birleştirilmiştir. Künye bilgilerinde, Sinematürk, Türk Sinema Araştırmaları Veri Tabanı (TSA) ve Internet Movie Database (IMDB) verileri karşılaştırmalı olarak kullanılmıştır. İstatistiksel analizin büyük kısmında, zaman içerisindeki dönüşümü göstermek için filmler beşer yıllık kesitler halinde gruplanmış, dolayısıyla ele aldığımız 20 yıllık dönem (1960-1979) dört kesite ayrılmıştır. Kesitler ve içerdikleri film sayısı şöyledir: 1960-1964 (10 film), 1965-1969 (33 film), 1970-1974 (39 film), 1975-1979 (18 film).

Ölçümlenen filmleri analiz ederken tür parametresi kısmen bilinçli kısmen de zorunlu bir tercih olarak incelemenin dışında bırakılmıştır. Bilindiği gibi bir film birden fazla türün özelliklerini gösterebilmektedir. Bu sebeple, filmlerin tür ve alt türlerinin sistematik ve tutarlı biçimde belirlenmesi gerekir. Türk Sinemasına ilişkin veri tabanlarında, filmlerin tür bilgileri tutarlı değildir, filmlerin tür ve alt türleri sistematik olarak belirlenmemiștir. Söz konusu tür verilerinin, başta Hollywood olmak üzere diğer endüstrilere ait tür verileriyle adapte edilebilirliği oldukça düşüktür. Dahası, uyarlama, kopya ve yeniden çekim yöntemleriyle üretilen Yeşilçam filmlerinin türünün belirlenmesi oldukça karmaşık hale gelmektedir. ${ }^{15}$ Dolayısıyla filmlerin türlerinin analize bir değişken olarak dâhil edilmesi, araştırmamızda daha sağlıklı sonuçlar vermek bir tarafa, yanıltıcı olacaktır.

\section{Bulgular}

Bu makalede, ürettiğimiz veri setini istatistiksel olarak incelediğimizde karşımıza çıkan başlıca iki grup bulguyu paylaşmak istiyoruz. Bunlardan birincisi yıllar içinde filmlerin OÇU'sundaki 
dönüşüme ilişkindir. İkinci grup bulgumuz ise, diyaloglu çekimlerin diyalogsuz çekimlere oranı hakkındadır. Söz konusu iki grup bulguya bakmak, hem Giriş Bölümünde belirttiğimiz amaçlara ulaşmamızı hem de çalışmamızın araştırma sorularını cevaplamamızı sağlamaktadır.

İlk olarak 1960'tan 1979'a uzanan süreçte, örneklemdeki filmlerin üslup özelliklerinin istatistiksel olarak nasıl bir dönüşüm gösterdiğine odaklanacağız. Şekil 1'de, örneklemdeki 100 filmin çekim uzunluklarına ilişkin değerler beşer yıllık kesitler halinde gösterilmiştir. Bu grafiğe baktığımızda, ortalama çekim uzunluğunun tedricen düştüğü görülmektedir. İlk beş yıllık kesitte 14,42 saniye olan ortalama çekim uzunluğu, son beş ylllı kesitte 7,05'e düşmüş, yani \%51,1 oranında kısalmıştır. Bu kısalma sabit bir hızla gerçekleşmemiş, beșer yıllık kesitler arasında farklı yüzdelerde değişimler olmuştur. Birinci kesitten ikinci kesite $(\% 26,07)$ ve üçüncü kesitten dördüncü kesite $(\% 28,20)$ geçişte çok belirgin bir kısalma görülürken ikinci kesitten üçüncü kesite geçişte bu oran çok daha düşük kalmıştır $(\% 7,87)$. MÇU’ya baktığımızda, filmlerin çekim uzunluğu değişimine bağlı olarak bu değerin de düşmekte olduğunu görüyoruz. Bununla birlikte, OÇU ve MÇU değerleri sayısal olarak azalırken, ikisi arasındaki oranda fazla bir değişim olmamaktadır. Nitekim MÇU/OÇU oranı, beşer yıllık kesitler arasında en az 0,50 ve en çok 0,55'tir. Yine aynı tabloda OÇU, beşer yıllık kesitler arasında düşüş gösterirken EUÇ değerinin de belirgin şekilde düştügünü görüyoruz. 196064 arasında 115,91 saniyeyle yaklaşık 2 dakikayı bulan EUÇ değeri, son beş yıllık kesit olan 1975-79 aralığında 82,44 saniyeye düşerek 1,5 dakikanın altına inmektedir. Bu değişim, geçen sürede filmlerdeki EUÇ ortalamasının \%28,87 oranında kısaldığı anlamına gelmektedir.

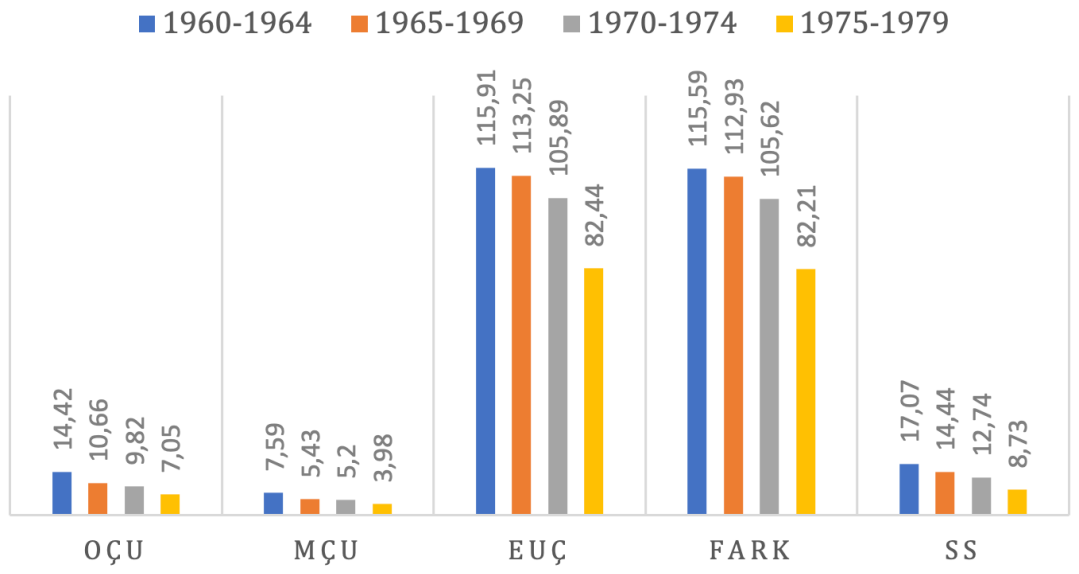

Şekil 1: Beşer yıllık kesitler halinde filmlerdeki çekim uzunluğu değişimi

Aynı grafikte, SS değerindeki değişim de dikkat çekicidir. Bu değerin yüksek oluşu, filmlerdeki çekim uzunluklarının OÇU'dan daha fazla saptığı, dolayısıyla çekim uzunluklarının daha geniş bir sayısal ölçek sunduğu anlamına gelmektedir. Beșer yıllık kesitler boyunca bu değerin görünür biçimde düşüyor olması, filmlerdeki çekim uzunluklarının OÇU'ya yaklaştığı ve filmlerin daha sınırlı bir çekim uzunluğu ölçeği sunduğu sonucunu doğurmaktadır. 1960-1964 kesitinden 1975-1979 kesitine kadar SS değeri radikal biçimde değişerek \%48,85 oranında düşmüştür.

1960-1979 döneminde, beşer yıllık kesitler halinde OÇU, EUÇ ve SS değerlerindeki düşüşü bir arada ele aldığımızda karşımıza daha bütünlüklü bir tablo çıkmaktadır. Bir yandan filmlerin OÇU'su düşmekte diğer yandan uzun çekimler kısalmakta ve filmler daha sınırlı bir çekim uzunluğu ölçeğine sahip olmaktadır. Dolayısıyla bu üç değerdeki düşüş bizi, 20 yıllık süreçte filmlerin, kelimenin geniş anlamıyla daha hızlı ve/veya ritmik kurgulandığı sonucuna götürmektedir. 
Araştırmamızın ikinci grup bulgusu, diyaloglu ve diyalogsuz çekimlerin oranına ilişkindir. Örneklemdeki filmlerde diyaloglu ve diyalogsuz çekimlerin dağılımında istatistiksel olarak nasıl bir farklılık görülmektedir? Şekil 2'de, ölçümlenen filmlerdeki diyaloglu ve diyalogsuz çekimlerin toplam uzunluklarının yüzdesel oranları gösterilmiştir. Bu tabloya baktığımızda, filmlerin ağırlıklı olarak diyaloglu çekimlerden oluştuğu görülmektedir. 1960-64 kesitinde diyaloglu çekimlerin oranı yaklaşık \%76 iken bu oran ikinci kesitte \%69'a, üçüncü kesitte de \%67'ye düşmüştür. Ancak son kesitte tekrar yükselerek \%75'e yaklaşmıştır.

Şekil 3'te, filmlerdeki diyaloglu ve diyalogsuz çekimlerin toplam sayıları yüzdesel olarak gösterilmiştir. Bu grafikte, diyaloglu çekimlerin toplam sayısının diyalogsuz çekimlerden daha fazla olduğu görülmektedir. Bir önceki grafikteki değerlerden sonra, diyaloglu ve diyalogsuz çekimlerin sayıları arasında böylesi bir fark görmek şaşırtıcı değildir. Ancak, aradaki farkın bir önceki grafiğe göre daha düşük olması dikkat çekicidir. Şekil 2'de, diyaloglu çekimlerin toplam uzunluğu \%67-76 değerleri arasında seyrederken, Şekil 3'te, diyaloglu çekimlerin toplam sayısı \%52-63 arasında değişmektedir. Bir başka ifadeyle, diyaloglu çekimlerin sayısal üstünlüğü, süre kıstasında daha belirginken sayı kıstasında gerilemektedir. Aradaki farkı anlamak için diyaloglu ve diyalogsuz çekimlerin ortalama uzunluklarına bakmamız gerekmektedir.

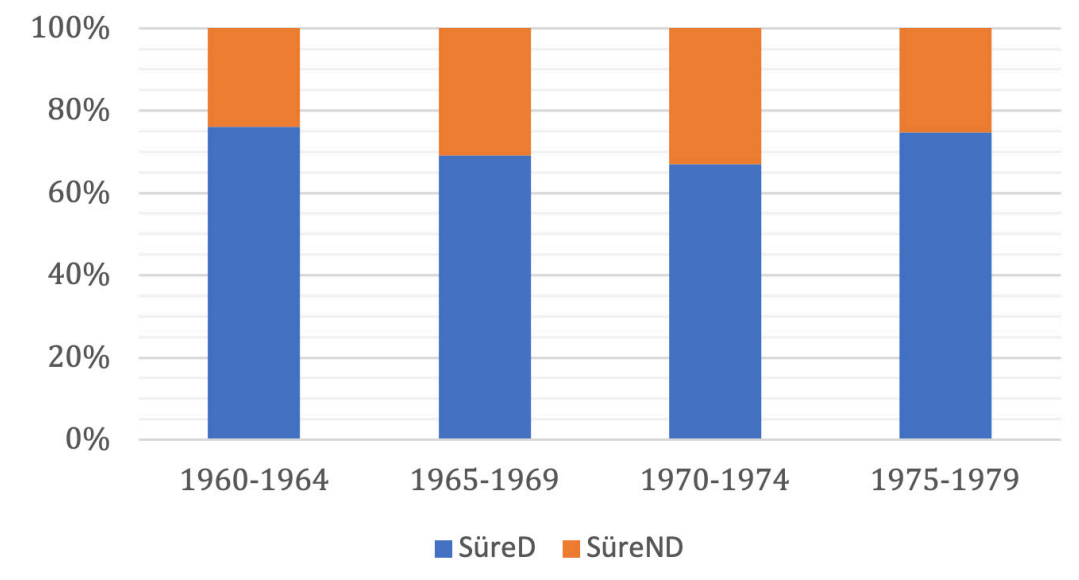

Şekil 2: Diyaloglu ve diyalogsuz çekimlerin uzunluklarının oranları

Şekil 4'te, hem diyaloglu ve diyalogsuz çekimlerin ortalama uzunlukları beşer yıllık kesitler halinde gösterilmiş hem de ayrı bir eğri ile Yeşilçam'ın genel OÇU değişimine yer verilmiştir. Bu grafiğe baktığımızda, iki sonuç çıkmaktadır. Birincisi, OÇU'daki genel düşüşe paralel olarak hem diyaloglu hem de diyalogsuz çekimlerin ortalama uzunlukları düşüş içindedir. İkincisi, beșer yıllık kesitlerin tümünde, diyaloglu çekimlerin ortalama uzunluğu, diyalogsuz çekimlerden belirgin şekilde daha uzundur. Söz konusu fark, Şekil 2 ve 3 arasındaki farkı anlamamızı da sağlamaktadır. Yeşilçam filmlerinde, genel bir eğilim olarak diyaloglu çekimler diyalogsuzlardan daha uzun olmuş dolayısıyla diyaloglu çekimlerin toplam sayısının yüzdesi, aynı çekimlerin toplam uzunluklarının yüzdesinden düşük kalmıştır.

$\mathrm{Bu}$ aşamada araştırmamızın bir başka sorusuna geçerek elimizdeki istatistiksel sonuçların, filmlerin üslubuyla endüstrinin üretim yapısı arasındaki ilişki bakımından anlamlı sonuçlar sunup sunmadığına bakabiliriz. Araştırmamızın diyaloglu ve diyalogsuz çekimlere ilişkin bulguları, Nezih Erdoğan'ın makalenin Giriş Bölümü'nde zikrettiğimiz argümanını hatırlatmaktadır. Erdoğan'a göre (1998, ss. 174-175) Yeşilçam endüstrisi 1960'ların ortalarından itibaren film üretimini hızlandırmak için sesli çekim yerine 
dublaja (post-senkronizasyon) yönelmiş aynı zamanda diyaloglu sahneleri açı-karşı açı tekniği yerine oyuncuların kameraya dönük konumlandırıldığı az sayıda çekimle kotarma yoluna gitmiştir. Şekil 2-4'e baktığımızda, filmlerin ağırlıklı olarak diyaloglu çekimlerden oluştuğunu ve diyaloglu çekimlerin diyalogsuz çekimlerden daha uzun olduğunu, dolayısıyla Erdoğan'ın savının istatistiksel olarak doğrulandığını görüyoruz. Yeşilçam yapımcıları, anlatısal olarak diyalog ağırlıklı filmler üretiyor, filmlerdeki diyalog sahnelerini mümkün olduğu kadar az kamera yerleștirmesiyle kotarıyor ve bu sahneleri daha sonra stüdyo ortamında dublaj yöntemiyle seslendiriyorlardı. $\mathrm{Bu}$ sayede, Erdoğan'ın iddia ettiği gibi kendine has bir üretim modeli geliştirerek üretimi hızlandırmış oluyorlardı.

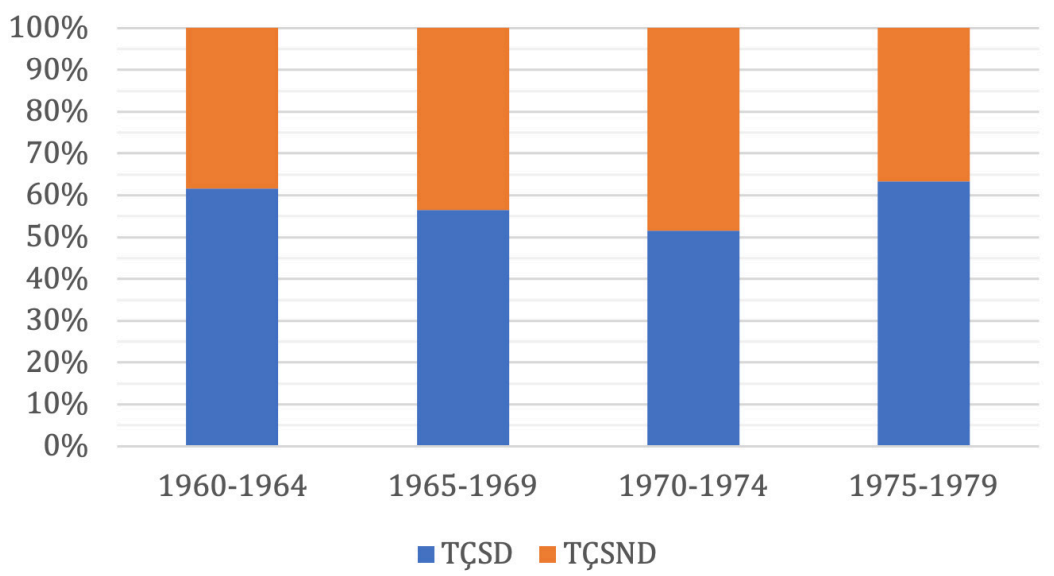

Şekil 3: Diyaloglu ve diyalogsuz çekimlerin toplam sayılarının oranı

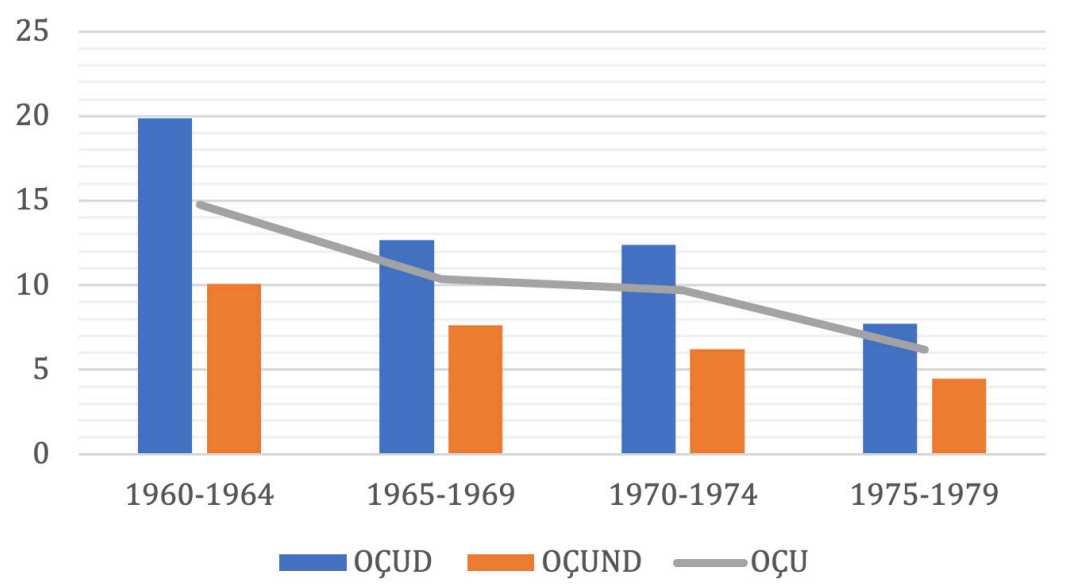

Şekil 4: Diyaloglu ve diyalogsuz çekimlerin ortalama uzunluklarındaki değişim

Son olarak araştırmamızın bütün bulgularını bir arada yorumlayarak makalemizin ana araștırma sorusunu cevaplamaya çalıștığımızda karşımıza nasıl bir tablo çıkmaktadır? Yani OÇU'ya ve buna bağlı diğer verilere bakarak 1960'tan 1979'a uzanan süreçte Yeşilçam filmlerinin üslup özelliklerindeki dönüşüm açıklanabilir mi? OÇU değerlerindeki değişime göre, Yeşilçam filmleri yıllar içinde daha hızlı/ritmik kurgulanır hale gelmişti. Öte yandan Yeşilçam, kendi üretim yapısından kaynaklanan üslup tercihini korumaktaydı. OÇU'daki genel kısalmaya rağmen endüstri, diyaloglu sahneleri bilinçli bir tercihle az kamera yerleştirmesi ve uzun çekimler yoluyla kotarma eğilimini sürdürüyordu. Dolayısıyla, üslup bakımından Yeşilçam filmleri hem bir dönüşüm hem de süreklilik içindeydi. 


\section{Sonuç ve Değerlendirme}

Bu makalede, Dijital İnsan Bilimleri ve film üslubunun istatistiksel analizine ait yaklaşım, yöntem ve araçların bir araya getirilmesi yoluyla Yeşilçam sinemasına ilişkin yeni bir tarihsel analizin ilk örneğini vermeye çalıștık. Araştırmamızda, 1960'lı ve 70'li yıllara ait bir grup Yeşilçam filmine metrik ölçümleme yapılarak bu ölçümlerden elde edilen istatistiksel veriler bir araya getirilmiş, oluşan veri setinin, ölçümlenen filmlerin biçimsel dönüşümünü açıklamak bakımından taşıdığı potansiyel ortaya konulmuştur. Beşer yıllık kesitler halinde bakıldığında, 1960'dan 1979'a kadar filmlerin biçimsel yapısına ilişkin bazı unsurların tedricen dönüștüğü ve filmlerin görece daha hızlı/ritmik kurgulandığı ortaya çlkmaktadır. Ancak bu dönüşüme paralel olarak Yeşilçam’ın kendi üretim ve anlatım yapısından kaynaklanan bazı üslup özelliklerini sürdürdüğü görülmektedir. Hem diyaloglu hem de diyalogsuz çekimlerin OÇU'su azalırken, diyaloglu sahnelerin az sayıda kamera yerleştirmesiyle ve uzun çekimlerle üretilmesi eğilimi yıllar içinde devam etmiştir. Bu iki bulgu bir araya getirildiğinde, ortaya Yeşilçam'ın biçimsel yapısına ilişkin daha bütünlüklü bir tablo çıkmaktadır. Bir taraftan, OÇU değerindeki tedrici kısalma bir dönüşüme işaret etmekte, diğer yandan endüstrinin üretim yapısına ilişkin bazı tercihler süreklilik arz etmektedir. Bu sonuç, istatistiksel ve nicel analiz yoluyla filmlerin biçimsel niteliklerini açıklamaya çalışmanın anlamlı bir çaba olduğunu ve filmlerin biçimsel niteliklerinin o filmlerin üretildiği daha geniş bir bağlamı açıklamak açısından da yararlı olduğunu göstermektedir. Bütün bu açılardan bakıldığında, filmlerden kapsamlı veri setleri üretilmesine ve bu veri setlerinin uzak okuma yöntemiyle incelenmesine dayanan bir metodolojinin, Türkiye sinema tarihi çalışmaları açısından büyük bir potansiyel taşıdığını ve araştırmamızın bu potansiyelin somut örneğini oluşturduğunu düşünüyoruz.

Bununla birlikte hem kullandığımız yöntem ve yaklaşımların hem de araştırmamızın mevcut halinin kimi yetersizlikler barındırdığının farkındayız. Çekim uzunluklarının ölçümlenmesine dayalı analiz yöntemi, filmlerin biçimsel niteliğine ilişkin önemli bir iç görü sunmakla birlikte bir filmin biçimsel niteliklerini anlamak için tek başına yeterli değildir. Bir filmin biçimsel yapısı, sinematografi, mizansen ve kurguya ilişkin onlarca bileșenin bir araya gelmesiyle ortaya çlkmakta ve bu bileșenlerin tekil özelliklerini aşkın, yeni bir bütünlük ortaya çıkarmaktadır. Araştırmanın ilerleyen aşamalarında, kamera hareketi, optik hareketler, çekim ölçeği, çekim türü, kamera açısı, 1şık ve renk değerleri gibi niteliklere bakılması öngörülmektedir. Bunların yanı sıra sinematografi kurallarının uygulaması (örneğin 30 derece ve 180 derece kuralları), karakterlerin çerçeve içinde görünme oranları, bakış yönleri, arka plan-ön plan ilișkisi gibi unsurlara da bakılabilir. Hakeza, tür ve estetik okul/akım parametreleri de analize dahil edilebilir. Söz konusu ek kıstaslara bakılabilmesi, FACT ve CCT araçlarından kaynaklanan yetersizliklerin aşılmasına bağlı olacaktır. Programın mevcut hali kullanılarak örneğin hem çekim ölçeğinin hem kamera hareketinin hem de kamera açısının veriye işlenmesi teknik olarak mümkün değildir. Mümkün olsa bile, aynı anda tüm bu verilerin işlenmesi bir filmin ölçümlenme süresini çok fazla uzatmakta yani araştırmanın iş akışını gerçekçi bir temelden uzaklaştırmaktadır. Dolayısıyla, ölçümleme işlemi için yeni araç ya da araçlar bulunması ve/veya geliştirilmesi ayrıca ölçümleme sürecinin kısmen otomatikleştirilmesi gerekecektir. Yeni bir ölçümleme aracının geliştirilmesi ya da mevcut açık kaynaklı bir aracın geliștirilerek kullanılması, araştırma sürecine programlama uzmanlarının dâhil olmasını ve araştırmanın daha kapsamlı bir ekip çalışmasına evirilmesini de zorunlu kılacaktır. 
Yeşilçam filmlerinin üslup özelliklerinin daha önce veri odaklı yöntemlerle analiz edilmediği göz önüne alınırsa, araştırmamızdaki 100 filmlik örneklem anlamlı ve kendi içinde tutarlı bir başlangıç oluşturmaktadır. Ancak 40 yıllık ömrü boyunca 5500'den fazla film üreten bir endüstrinin biçimsel özelliklerini kapsamlı olarak açıklamak için daha geniş bir örnekleme ihtiyaç duyulacağı da açıktır. Örneklemin sadece sayısal olarak değil, temsil edilen kişiler, film türleri ve dönemler açısından da geliştirilmesi gerekecektir.

Araştırmamızın bir diğer sınırını, yaptığımız analizin toplumsal ve kültürel boyutunun yetersiz kalması oluşturuyor. Bilindiği gibi Yeni Sinema Tarihi yaklaşımı, filmlerin tarihinin dağıtım, gösterim, seyir ve alımlama süreçleriyle birlikte toplumsal ve kültürel perspektiften ele alınmasını ön plana çıkarmaktadır. Yeşilçam endüstrisinin bu boyutlarına ilişkin elimizde maalesef veri setleri bulunmamaktadır. Yeşilçam’ın karmaşık dağıtım ve işletme mekanizmaları ya da hasılat kayıtlarının ve doküman arşivlerinin yokluğu gibi etmenler söz konusu türden veri setlerinin bulunmasını ya da yaratılmasını güçleştirmektedir. Ancak bu güçlüğe rağmen arşiv taraması ve coğrafi kodlama yöntemleriyle dağıtım ve seyir süreçlerine ilişkin veri setleri yaratılabilir. $\mathrm{Bu}$ açıdan, Yeşilçam dönemine ilişkin son yıllarda giderek artan sözlü tarih çalışmaları ve Türkiye'de seyir kültürüne ilişkin araştırmalar büyük önem taşımaktadır (Gökmen, 2019; Şanlıer Yüksel ve Çam, 2019a, 2019b; Akbulut, 2018; Medin, 2018, 2017; D. Kaya, 2017; Akbulut, 2014; Öztürk, 2013). Bu türden çalışmaların sonuçlarının filmlerin biçimsel özelliklerine ilişkin araştırmalarla ilişkilendirilmesi yoluyla, Yeşilçam dönemi Türkiye sineması hakkında daha bütünlüklü okumalar yapılabilir. Bu bakımdan, Dijital İnsan Bilimleri büyük bir potansiyel sunmaktadır. Bu potansiyel, farklı veri setlerinin dönüştürülmesinde, sürdürülmesinde ve birbirine adapte edilmesinde yatmaktadır.

\section{Notlar}

1 Bu araştırmanın bazı bulguları daha önce üç ayrı bilimsel toplantıda paylaşıımış olup bildirilerin hiçbiri yayınlanmamışır: Şavk, 2018a, 2018b, 2018c. Yorum ve önerileri için Nezih Erdoğan, Peter Krämer, lan Christie ve Gustav Deutsch'a teşekkür ederiz. Makalenin yayına hazıllandığı sırada, Gustav Deutsch'un yaşama veda ettiğini üzüntüyle öğrendik. Bu büyük sanatçıyı saygıyla anıyoruz. Bazı film verilerinin Cinemetrics veri tabanına yüklenmesi ve hatalı ölçümlerin veri tabanından temizlenmesiyle bizzat ilgilenen Yuri Tsivian'a, veri setinin analize uygun hale getirilip yorumlanmasındaki katkısndan ötürü Ali Oğulcan IIlhan'a ve en önemlisi, filmleri tek tek ölçümleyerek bu araştırmayı mümkün kılan değerli öğrencilerimize müteşekkiriz.

2 Nejat Ulusay'ın Melez İmgeler kitabı (2008) bu sınırın aşılması bakımından öncü bir çalışma olmuş, takip eden yıllarda yerli sinemanın ulusaşııı süreçlerdeki konumuna ilişkin başka çalışmalar da ortaya çıkmıştır.

3 Türkiye'de sinema tarihyazımının geriye dönük bir inşa süreci olarak nasıl işlediği hakkında bir örnek için bkz. Kaya Mutlu, 2007.

4 Tüm sayısal veriler için Türk Sinema Araşırımaları (tsa.org.tr) veri tabanından yararlanılmıştır. Arslan'ın, yukarıda anılan dönemlendirmesi esas alınarak veri tabanında 1950-1989 aralığı tarandığında toplam 5595 film kaydına ulaşılmaktadır: https://www.tsa.org.tr/tr/arama/detaylifilm/1/?search_keyword=\&search_type=1\&search_movie_year_ first=1950\&search_movie_year_last=1989, erişim: 15.02.2020. Bu sayının, belgesel ve kısa filmleri de kapsadığı, öte yandan henüz veri tabanına girilmeyen filmler bulunabileceği göz önünde bulundurulmalıdır.

5 Dublaj yerine post-senkronizasyon kavramı da kullanılabilir. Dublaj (ing. dubbing) sinema terminolojisinde birbiriyle ilişkili birkaç anlama sahiptir. Bunlardan biri, çekilen görüntülere daha sonra eklenmek üzere diyalogların post-prodüksiyon aşamasında yeniden kaydedilmesi (post-senkronizasyon), diğeri de bir filmdeki diyalogların başka bir dilde yeniden kaydedilip eklenmesidir (Kuhn ve Westwell, 2012, ss. 128-129).

6 Yakın zamanda yapılan bir belgeselde hem araşıtımacılar hem de Yeşilçam profesyonelleri, endüstride hakim olan iktibas, uyarlama, yeniden çevrim ve intihal mekanizmalarını detaylı olarak anlatmışlardır (C. Kaya, 2014). Aynı belgeseldeki röportajında oyuncu Izzet Günay, daha önce başarılı olan filmlerdeki anlatı unsurlarının harmanlanmasıyla oluşturulan filmler için "aşure film" tabirini kullanmaktadır. 
7 Bu durumun en bilinen örneği Dünyayı Kurtaran Adam filmidir (İnanç, 1982). Dünyayı Kurtaran Adam, Yıldız Savaşları (Lucas, 1977) filminden alınan görüntüleri ve Indiana Jones: Kutsal Hazine Avcıları (Spielberg, 1981) filmiyle Savaş Yıldızı Galactica (Larson, 1978) dizisinden alınan müzikleri içermektedir (Smith, 2017, s. 68).

8 Sinema tarihçiliğinin ilgi çekici polemiklerinden biri Bordwell, Thompson ve Salt arasında geçmiş olup, bu polemik 0ÇU'ya farklı bakış açılarını göstermesi bakımından dikkate değerdir (Bordwell ve Thompson, 1986; Salt, 1987)

9 Salt'ın istatistiksel çalışmaları için özellikle kitabın ikinci ve üçüncü baskılarına bakılabilir.

10 Proje sitesinin teori ve tartışma bölümlerinde, bu araşıırmacıların kaleme aldığı çok sayıda makale ve not yer almaktadır: http://cinemetrics.Iv/articles.php, http://cinemetrics.Iv/discussion.php, erişim: 24 0cak 2019.

11 Elinizdeki makalede kitabın 2007 baskısından yararlanılmıştır (Moretti, 2007).

12 Kitapların elektronik ortama aktarıması fikri kuşkusuz 1990'lardan eskiye dayanır. Örneğin bu alandaki öncü girişimlerden biri olan Gutenberg Projesi 1971'de hayata geçirilmiştir. Ancak dünya genelinde dijitalleştirilen metin sayısı 1990'larda dramatik biçimde artmıştır.

13 Ölçümler veri tabanında oluşturulan "Yesilcam (1960s and 70s)" başlıklı çevrimiçi laboratuvarda toplanmıştır: http:// www.cinemetrics.Iv/lab.php?ID=202, erişim: 22.04.2020. Örneklemdeki filmlerin tam listesi için söz konusu çevrimiçi laboratuvarın Notlar kısmına bakınız.

14 Veri tabanına sonuçları yükleyen isim (submitted by) aynı zamanda ölçümü yapan öğrenciyi göstermektedir. Veri tabanının yükleme hatası verdiği dönemde, öğrencilerin bilgisayarlarına kaydettikleri ölçüm sonuçları daha sonra tarafımızdan veri tabanına yüklenmiştir. Bu gruptaki ölçüm sonuçlarının yorum kısmında ölçümü yapan öğrencinin ismi ayrıca belirtilmiştir (measured by ....).

15 Yeşilçam sinemasının belli türleri üzerine azımsanmayacak bir literatür mevcuttur. Örneğin melodramlar için bkz. (Akbulut, 2012, 2008; Tunalı, 2006). Ayrıca Yıldıım'ın (2016) çalışması, Yeşilçam'ın başat türlerini belirlemeye yönelik önemli bir girişimdir.

\section{Kaynakça}

Abisel, N. (2005). Türk Sinemasında Film Yapımı Üzerine Notlar. Türk Sineması Üzerine Yazılar içinde . Ankara: Phoenix Yayınevi.

Adams, B., Dorai, C. ve Venkatesh, S. (2002). Formulating Film Tempo: The Computational Media Aesthetics Methodology in Practice. C. Dorai ve S. Venkatesh (Ed.), Media Computing: Computational Media Aesthetics içinde (ss. 57-84). New York: Springer Science+Business Media.

Akbulut, H. (2008). Kadına Melodram Yakışır: Türk Melodram Sinemasında Kadın İmgeleri. İstanbul: Bağlam Yayıncılık.

Akbulut, H. (2012). Yeşilçam'dan Yeni Türk Sinemasına Melodramatik İmgelem. İstanbul: Hayalperest Yayınevi.

Akbulut, H. (2014). Sinemaya Gitmek Ve Seyir: Bir Sözlü Tarih Çalışması. Elektronik Mesleki Gelişim Ve Araștırmalar Dergisi, 2(2), 1-16.

Akbulut, H. (2018). Bir Seyirci Araştırmasından Etnografik Deneyimler ve Hikâyeler. Folklor/Edebiyat, 24(95), 13-34. doi:10.22559/folklor. 246

Akser, M. (2014). Towards a New Historiography of Turkish Cinema. M. Akser ve D. Bayrakdar (Ed.), New Cinema, New Media: Reinventing Turkish Cinema içinde (ss. 48-66). Newcastle upon Tyne: Cambridge Scholars Publishing.

Arslan, S. (2011). Cinema in Turkey: A New Critical History (1. bs.). Oxford, New York: Oxford University Press.

Baxter, M. (2014). Notes on Cinemetric Data Analysis. http://cinemetrics.lv/dev/ Cinemetrics_Book_Baxter.pdf adresinden erişildi. 
Bordwell, D. (2006). The Way Hollywood Tells It: Story and Style in Modern Movies. Berkeley: University of California Press.

Bordwell, D. ve Thompson, K. (1986). A Salt and Battery [Controversy \& Correspondence]. Film Quarterly, 40(2), 59-62.

Brabham, D. C. (2013). Crowdsourcing. Cambridge: The MIT Press.

Çam, A. (2016). Derviş Zaim: Bir Mekân Sineması'na Doğru. (Yayımlanmamış phd dissertation). Galatasaray Üniversitesi, İstanbul.

Erdoğan, N. (1998). Yeşilçam'da Beden ve Mekânın Eklemlenmesi Üzerine Notlar. Doğu Batı, (2), 5. baskl, 173-181.

Gardner, T. (2012). Close Reading. (R. Greene, S. Cushman, C. Cavanagh, J. Ramazani ve P. Rouzer, Ed.)The Princeton Encyclopedia of Poetry and Poetics: Fourth Edition. Princeton: Princeton University Press.

Gökmen, E. (2019). Samsun' da Sinema Mekanları Üzerine Bir Sözlü Tarih Çalışması. Selçuk İletişim, 12(1), 325-350. doi:10.18094/josc.412240

Habib, M. A. R. (2005). A History of Literary Criticism: From Plato to the Present. Blackwell Publishing.

Howe, J. (2016). The Rise of Crowdsourcing. Wired, 14.

İnanç, Ç. (1982). Dünyayı Kurtaran Adam.

İnceoğlu, Ç. (2015). Devinden Mizansenden Huzursuz Kameraya: Yeşilçam'da Zum. Akdeniz İletişim Dergisi, (23), 9-25.

Internet Archive: About IA. (t.y.). 31 Ocak 2019 tarihinde https://archive.org/about/ adresinden erișildi.

Jänicke, S., Franzini, G., Cheema, M. F. ve Scheuermann, G. (2015). On Close and Distant Reading in Digital Humanities: A Survey and Future Challenges [STAR - State of the Art Report] (ss. 1-21). Eurographics Conference on Visualization (EuroVis), sunulmuş bildiri. https://www.informatik.uni-leipzig.de/ stjaenicke/Survey.pdf adresinden erişildi.

Kaya, C. (2014). Remake, Remix, Rip-Off: About Copy Culture \& Turkish Pop Cinema. Belgesel.

Kaya, D. (2017). Eski İzmir Sinemaları ve Yıldız Sineması: Mekân, Toplum, Seyir. sinecine: Sinema Araştırmaları Dergisi, 8(2), 93-138. doi:doi.org/10.32001/sinecine.536527

Kaya Mutlu, D. (2007). The Russian Monument at Ayastefanos (San Stefano): Between Defeat andRevenge, Remembering and Forgetting. Middle Eastern Studies, 43(1), 75-86.

Kuhn, A. ve Westwell, G. (2012). Dubbing. Dictionary of Film Studies. Oxford: Oxford University Press.

Larson, G. A. (1978). Savaş Yıldızı Galactica.

Lebert, M. (2008). Project Gutenberg (1971-2008). http://www.gutenberg.org/ ebooks/27045 adresinden erişildi.

Lucas, G. (1977). Yıldız Savaşları. http://www.imdb.com/title/tt0076759/ adresinden erişildi. 
Manovich, L. (2013). Visualizing Vertov. http://manovich.net/content/04-projects/078visualizing-vertov/74_article_2013_sm.pdf adresinden erişildi.

Medin, B. (2017). Değișen Sinema Seyir Kültürünü Sözlü, Yazılı ve Elektronik Kültür Bağlamında Anlamak. Selçuk İletişim, 10(1), 357-386. doi:10.18094/josc.306696

Medin, B. (2018). Dijital Kültür, Dijital Yerliler ve Günümüzdeki Yeni Film Seyir Deneyimleri. Erciyes İletişim Dergisi, 5(3), 142-158.

Moretti, F. (2000). Conjectures on World Literature. New Left Review, II, (1), 54-68.

Moretti, F. (2007). Graphs, Maps, Trees: Abstract Models for Literary History. London: Verso.

Okumuş, F. (2010). Sinema Tarihyazımına Farklı Bakmak ve Türk Sineması Tarihyazımı İçin Yöntem Arayışı. (Yayımlanmamış phd dissertation). Anadolu Üniversitesi, Eskişehir.

Özen, E. (2009). Özön'ün Paltosundan Kurtulmak: Türkiye Sineması Tarihi Çalışmalarının Eleștirel Bir Değerlendirmesi. iletişim: Araștırmaları, 7(1-2), 13-47.

Özön, N. (2010). Türk Sinema Tarihi 1896-1960 (3. bs.). İstanbul: Doruk Yayımcılık.

Öztürk, S. (2013). Türkiye'de Sinema Mekânlarını Sözlü Tarih Üzerinden Anlamak. Milli Folklor, 25(98), 19-31.

Redfern, N. (2012a). Nick Redfern. (2012). Shot length distributions in the short films of Laurel and Hardy. Cine forum, 14(5), 37-71.

Redfern, N. (2012b). The impact of sound technology on the distribution of shot lengths in Hollywood cinema, 1920 to 1933. CINEJ Cinema Journal, 2(1), 77-94. doi:10.5195/ cinej. 2012.50

Redfern, N. (2013). Film Studies and Statistical Literacy. Media Education Research Journal, $4(1), 58-73$.

Redfern, N. (2014). Comparing the Shot Length Distributions of Motion Pictures using Dominance Statistics. Empirical Studies of the Arts, 32(2), 257-273. doi:10.2190/ EM.32.2.g

Redfern, N. (2015). The log-normal distribution is not an appropriate parametric model for shot length distributions of Hollywood films. Digital Scholarship in the Humanities, 30(1), 137-151. doi:10.1093/llc/fqs066

Redfern, N. (t.y.). Shot Length Distributions in the Early Film of Charles Chaplin, 1-5.

Salt, B. (1974). Statistical Style Analysis of Motion Pictures. Film Quarterly, 28(1), 13-22. doi:10.2307/1211438

Salt, B. (1987). Reply to Bordwell \& Thompson [Correspondence and Controversy]. Film Quarterly, 40(4), 59-61.

Salt, B. (2009). Film Style and Technology: History and Analysis (3. bs.). London: Starword.

Smith, I. R. (2017). Hollywood Meme: Transnational Adaptations in World Cinema. Edinburgh: Edinburgh University Press.

Spielberg, S. (1981). Indiana Jones: Kutsal Hazine Avcıları.

Stindt, G. otto. (1926). Bildschnitt. Die Filmtechnik, 2(7). 
Şanlıer Yüksel, İ. ve Çam, A. (2019a). Çukurova'da 1960-1980 Dönemi Sinema Pratiklerinin Özel Bir Örneği: Yörük Filmleri. sinecine: Sinema Araştırmaları Dergisi, 10(2), 291320. doi:10.32001/sinecine.639715

Şanlıer Yüksel, İ. ve Çam, A. (2019b). Adana Sinema Tarihinden Kadınların Seyir Deneyimine Dair Fragmanlar. Kültür ve İletişim, (44), 63-94. doi:10.18691/ kulturveiletisim.629046

Şavk, S. (Kasım 2018a). Between Youtube and history: An attempt for developing a distant reading of Turkish cinema during 1960s and 70s [Bildiri]. ECREA 7th European Communication Conference: Centres and Peripheries: Communication, Research, Translation, Lugano.

Şavk, S. (Kasım 2018b). How Social Platforms Replace Archives When There are No Archives or A Statistical Approach to Yeşilçam [Bildiri]. Forgetting the Archive: Exploring Past Images in the Digital Age, İstanbul.

Şavk, S. (Ekim 2018c). Video Paylaşım Sitelerindeki Yeşilçam Filmlerini Kuşbakışı Olarak Okuma Denemesi [Bildiri]. Dijital Çağda İletişim Sempozyumu, Mersin.

Thompson, K. (2005). Herr Lubitsch Goes to Hollywood: German and American Film After World War I. Amsterdam: Amsterdam University Press.

Tsivian, Y. (2009). Cinemetrics, Part of the Humanities' Cyberinfrastructure. M. Ross, M. Grauer ve B. Freisleben (Ed.), Digital Tools in Media Studies: Analysis and Research. An Overvie içinde . Bielefeld: Verlag.

Tunalı, D. (2006). Batıdan Doğuya, Hollywood'dan Yeşilçam'a Melodram: Zihniyet ve Kültür Etkileşimleri Çerçevesinde Yeşilçam Melodramı'na Bakış. Ankara: Aşina Kitaplar.

Ulusay, N. (2008). Melez Imgeler: Sinema ve Ulusötesi Oluşumlar. Ankara: Dost Kitabevi.

Valatsou, D. (2014). Crowdsourcing Digital History Online. Historein, 14(2), 30-42.

Yıdırım, T. (2018). Yeşilçam’da Polisiyenin Eleştirel Dönüşümü: Toplumsal Gerçekçi Sinema Hareketinin Amblemi Olarak Gecelerin Ötesi. Erciyes İletişim Dergisi, 5(4), 599-630. doi:10.17680/erciyesiletisim.422076

Yıldırım, T. (2016). Türk Sinemasının Estetik Tarihi: Standart Türlere Giriş 1948-1959 (1. bs.). İstanbul: Es Yayınları.

\section{Veritabanları}

Internet Movie Database (www.imdb.com)

Sinematürk Sinema Veritabanı (www.sinematurk.com)

Türk Sinema Araştırmaları (www.tsa.gov.tr)

Cinemetrics Database (www.cinemetrics.lv/database) 


\title{
Old Images, New Phenomena: A Distant Reading Attempt for Stylistic Properties of Yeşilçam Films
}

\author{
Serkan Şavk (Asst. Prof. Dr.)
}

\section{Extended Abstract}

Between the late 1940s and late 1980s, Turkey had an established and highly standardized film industry known with the name of Yeşilçam. During its lifetime of 40 years, this industry produced ca. 5500 films in different genres mainly for being distributed in Turkey's domestic film market. Yeşilçam was a productive industry thanks to a couple of strategies and mechanisms such as switching to dubbing (post-synchronization), using fewer camera instalments (Erdoğan, 1998, ss. 174-175), receiving advance payment from movie-theatre managers (Abisel, 2005, s. 106), and adapting, repeating or copying already existing films (C. Kaya, 2014). Even though Yeşilçam produced hundreds of films, the majority of them were not accessible neither in the archives nor at commercial platforms until recently. The issues of access to Yeşilçam films resolved suddenly, as production and distribution companies started to share their collections on YouTube during the last 5-6 years. This research focuses on this recent development which might be defined as the opening of a bulk of Yeşilçam films to remote access on digital media.

The main goal of this article is to study the stylistic properties of Yeşilçam films with the distant reading approach by using methods and tools from digital humanities and statistical analysis of film style. The second goal is to relate the formal and stylistic properties of films to the internal dynamics and historical development of the film industry. Thus, we demonstrate the potential of an analysis method that is derived from the creation of complex data sets out of visual resource bulks. To this aim, we focus on the period between 1960-1979 that Savaş Arslan (2011) defines as the High Yeşilçam Period. To be the initial step of our attempt, we created a film sample which mainly includes works of three mainstream directors of the industry: Osman Seden (19241998), Orhan Elmas (1927-2002) and Orhan Aksoy (1930-2008). Our intention was doing metric measurement of each film intending to create detailed average shot length (ASL) data. The metric measurement is a time consuming and labour-intensive process. Therefore, we used crowdsourcing, a very popular method among digital humanists and big data experts, for managing the measurement process. Each participant undertook the measurement of a given film by using either the Frame Accurate Cinemetrics Tool (FACT) or the Classical Cinemetrics Tool (CCT) that are developed as part of the Cinemetrics project at Chicago University. The results of individual measurements are uploaded to the Cinemetrics database and compiled under the lab titled Yesilcam (the 1960s and 70s). After cleaning and optimizing the results, we ended up with an extensive data set that covers statistical results for 100 films.

The main methodological approach of our paper is distant reading, which is manifested by Moretti (2007) and gradually became very common among digital humanists and big data experts. What makes distant reading a convenient approach is its capability of dealing with huge bulks of resources by extracting data sets from them and enabling us to make long term and comprehensive analysis. In this study, by approaching our data set with the distant reading approach we ask the following research questions: Statistically, how do the stylistic properties of the films in the sample transform from 1960 to 1979 ? 
What is the statistical difference regarding the distribution of dialogue and non-dialogue shots in the same films? Do the statistical results demonstrate a meaningful relation between the style of the films and the production mode of the industry? In response to these questions, we argue that the stylistic properties of Yeşilçam films demonstrate both change and continuity during the given period. The ASL value of the films becomes shorter while the tendency of making dialogue-oriented films continues. We also contend that the transforming ASL values of the films overlap with the production mode of the industry.

Keywords: Cinema, Turkish Cinema, Film History, Digital Humanities, Statistical Analysis Of Film Style. 